\title{
ACTIONS AND CHANGES IN THE LOGISTICS POLICY IN PANDEMIC TIMES: A CASE STUDY OF A FUNERAL HOME
}

\author{
M. V. D. DE ASSUNÇÃO ${ }^{1}$, M. V. P. DE ARAÚJO², F. A. F. DA ROCHA ${ }^{3}$, A. T. P. GONÇALVES ${ }^{4}$, J. I. M. P. DE
} LIMA $^{5}$

Instituto Federal de Educação, Ciência e Tecnologia do Rio Grande do Norte ${ }^{1,3}$, Universidade Federal do Rio Grande do Norte ${ }^{2,5}$, Universidade Federal de Pernambuco ${ }^{4}$ ORCID ID: http://orcid.org/0000-0002-3384-1899¹ marcus.assuncao@ifrn.edu.br ${ }^{1}$

Submetido 14/03/2020 - Aceito 07/12/2020

DOI: $10.15628 /$ holos.2020.11291

\begin{abstract}
The purpose of this article is to understand the actions and processes of change made in the logistics policy of a funeral home operating in Northeast Brazil to cope with the period of the COVID-19 pandemic. The paper addresses an exploratory case study with a qualitative analytical approach, which used a semi-structured interview script to collect data from the operations manager of the company in question, videoconferenced in July 2020. The survey was designed in four stages: (1) construction of theoretical subsidies; (2) interview with the operations manager;
\end{abstract}

(3) return to the interviewee to consolidate the collected data; (4) analysis of the main changes occurring in the organisation's logistics process during the pandemic. The results of the analysis helped conclude that the context of the public health crisis generated actions in and a need to re-adapt the firm's logistics policy for transport, procurement and inventory, in order to ensure continuity of the funeral services rendered, without detriment to the consumers of the funeral plans and new clients.

Keywords: Logistics, Funeral Industry, Pandemic, COVID-19.

\section{AÇÕES E MUDANÇAS NA POLÍTICA DE LOGÍSTICA EM TEMPOS DE PANDEMIA: UM ESTUDO DE CASO EM UMA EMPRESA DO SETOR FUNERÁRIO}

\section{RESUMO}

O objetivo deste artigo é compreender as ações e os processos de mudanças realizados na política de logística de uma empresa do segmento funerário que atua no nordeste brasileiro para atender ao período da pandemia da COVID-19. A pesquisa trata de um estudo de caso de caráter exploratório e com abordagem de análise qualitativa, que utilizou um roteiro de entrevista semiestruturada para coleta dos dados junto ao gerente de operações da referida empresa, o qual foi aplicado por meio de videoconferência no mês de julho de 2020. O design da pesquisa seguiu quatro etapas, quais sejam: (1) construção de subsídios teóricos; (2) entrevista com o gerente de operações; (3) retorno ao entrevistado para consolidação dos dados coletados; (4) análise das principais mudanças ocorridas nos processos logísticos da organização no período de pandemia. Os resultados da análise permitiram concluir que o contexto da crise na saúde pública gerou ações e uma necessidade de readequação na política logística de transportes, compras e estoques da empresa, a fim de garantir a continuidade da prestação de serviços funerários, sem prejuízo aos consumidores dos planos funerários e de novos clientes.

Palavras-Chave: Logística, Setor Funerário, Pandemia, COVID-19. 


\section{INTRODUCTION}

Considerations on experiences arising from the outbreaks of the Severe Acute Respiratory Syndrome (SARS) in 2002, Ebola between 2013 and 2016 (Brooks et al., 2020) and the H1N1 pandemic in 2009 (Bajardi et al., 2011), in addition to the World Health Organization (WHO) discussions, have already indicated the need for countries to pre-plan some public health actions in order to minimise possible crises triggered by the emergence of a new pandemic such as that of the COVID-19 (WHO, 2007).

This new disruptive moment caused by the pandemic of the new coronavirus not only impacted the health services but also caused changes in almost all areas of life in society. In addition to the consequences of the outbreak in the demand for goods and services, the organisations need, in this context, to deal with the risks arising from the increase in the error in inventory forecasting, shortage of inputs and resilience in the procurement process, perhaps causing a deficit or surplus of items in the warehouses (Assunção et al., 2020).

Julianelli (2020) comments that, although it is impossible to completely eliminate this risk, since historic data do not help to anticipate a decline, it could be mitigated by adopting inventory planning methods. Pellegrini and Fogliatto (2001) stress that by means of forecasting techniques, it is possible to retrieve information from available past demandrelated data, allowing mathematical modelling of its behaviour, in which the assumption that this behaviour will continue enables forecasts whose quality and accuracy are far superior to those of the intuitive predictions.

Therefore, the challenge in this global pandemic context is now as follows: how to make changes in the logistics processes at a time of discontinuity and instability, considering the non-repetition of patterns observed in past data at a future time?

According to Assunção et al. (2020), numerous changes have been made in developing logistics activities as a result of the COVID-19 pandemic, namely: further losses in the inventories due to obsolescence, damage or expiry date; out-of-stocks of items more in demand during the pandemic, such as, for example, medication, cleaning and personal hygiene products, and facemasks; higher freight costs caused by the bottleneck in the transport sector as a result of the especially high demand for fractionated freight; search for alternative suppliers to meet the demand of the most wanted items, and so on.

In this challenging environment, some observations were now fundamental: which data would be suitable for comparison purposes? Are those data reliable and are they available? How do we apply mathematical models and use qualitative data together in order to support the decision-making process in inventory management, procurement and distribution and transport operations, considering this new demand pattern behaviour?

Concerning the firms operating in marketing funeral goods and services, as mentioned by Virgulino and Figueiredo (2018), one of the characteristics concerning the industry is the unpredictability of demand, since it is unable to accurately forecast how many deaths will 
occur. Another point to be considered, according to the authors, is the possibility of some companies in the industry deciding on an investment policy of high inventory levels for funeral urns, thereby preventing any risk of interruption, because suppliers are concentrated in Southeast Brazil.

In the funeral service industry, the task faced by nations throughout the world is how to deal with the human physical remains (Rugg, 2020). Also according to the author, in modern societies, the state generally sets up a legal burial and cremation structure and, in some cases, this structure includes a strategic planning requirement to ensure the suitability of such services.

Corpse management is the specific characteristic that determines the exact form of a nation's funeral culture (Walter, 2012). Funeral practices vary between different countries, due to many factors, such as: culture, religion, demography, medicalization and migration (Walter, 2005, 2012). These differences are noticeable in funeral rites but also in cremation charges, cemetery management and state regulations (Sloane, 1991; Goody \& Poppi, 1994; Suzuki, 2000; Kopp \& Kemp, 2007; Akyel, 2011; Rugg, 2015).

In Western and predominantly Christian countries, bodies are buried in graves in cemeteries, whose systems include "age old" state provision and some reminders of a "traditional" burial, the funeral and burial spaces burial provided by the religious authorities (Jacobs, 2008).

Cemeteries are owned and managed by different types of agencies, public, private or linked to religious communities (Rugg, 2020), as in the United Kingdom (Rugg \& Parsons, 2018) and The Netherlands (Mathijssen \& Venhorst, 2019). In Scandinavian countries, however, such as Sweden and Norway, cemeteries are mainly under church control (Hadders, 2013). But in the USA, according to Klaufus (2016), private corporations manage funeral services, sharing responsibility with the state.

These funeral systems were challenged by the new coronavirus pandemic, the casualties of which by the end of September 2020 had reached over a million worldwide (WHO, 2020). It is important to understand the changes triggered in the logistics processes of this market segment.

Strategic logistics strives for systemic integration of the different operations and logistics activities, through processes wherein each microprocess plays a vital role in the final performance of the organisational strategy (Mentzer et al., 2004). Logistics processes are performed through primary and support activities with a view to achieving the strategic objective of logistics, given the complexity of operations in the supply chains, especially with regard to the transport, inventory, handling and procurement processes (Ballou, 2007).

Decisions to maintain inventories and become more competitive by performing shorter delivery lead times or minimising storage costs, but which directly impact client availability, are some of the issues to be defined by this industry (Bowersox, Closs, Cooper \& Bowersox, 2013). It is worth mentioning that the costs inherent to the inventory management 
processes, for example, could vary around $30 \%$ of the item's value (Ballou, 2007).

Procurement management, however, plays a key role in any organisation, since it is responsible for introducing new technologies that impact directly on improving the quality of the products, selecting qualified suppliers, guaranteeing the resupply and cutting procurement costs, ensuring a better profit margin in the sold products (Mentzer et al., 2004).

Distribution is responsible for point-to-point delivery. Flexible distribution allows a firm to adapt its deliveries to the new demands imposed by the different scenarios (Swafford, Ghosh \& Murthy, 2006).

Diversity and complexity of the activities comprising the logistics processes listed in this study require integration and cooperation with each other, since the work done by one interferes in the other's results (Bowersox, Closs, Cooper \& Bowersox, 2013), since they are part of the firm's logistics policy. Through coordinated action and efficient performance of its activities, logistics collaborates with improving the quality of the products; it cuts times and production costs; optimises material handling and storage processes; helps cut distribution costs and lead time; and ensures the supply of goods and services, playing a key role in adding value to the client (Mentzer et al., 2004; Bowersox, Closs, Cooper \& Bowersox, 2013).

Therefore, based on the complexity presented by the logistic processes described by the specialised literature, the survey question of the study herein can then be formulated: how did a firm in the funeral industry prepare and make changes in its logistics processes to respond to the COVID-19 pandemic period?

The overall objective, therefore, is to understand the actions and processes of change in the logistics policy of a firm in the funeral industry, which operates in Northeast Brazil to respond to the COVID-19 pandemic period?

This study contributes to building knowledge related to the logistics processes of the funeral industry, a topic still incipient in literature, but open to more in-depth investigations, given its importance for the social strata.

This article herein consists of an introduction that places the case study in context, by also addressing a brief review of the literature. The second section addresses the methodology used in the study, outlining the executive stages of the survey. The results of the interview with the manager and the analysis of the literature are discussed in section 3. The last section of the study covers the conclusions and their contributions to the specialised literature.

\section{METHODOLOGY}

The study is characterised as an exploratory case study, therefore is in-depth and of a special nature. To be considered a case study, the study unit has to be an object of investigation in which the knowledge produced therein needs to be relevant, either for 
comparative purposes or due to the important nature and contribution of the organisation to understand the phenomenon being studied (Yin, 2018).

The case studies have no standard or specific format, since the study is considered the "heart" of the theory's construction (Eisenhardt, 1989). Alves-Mazzoti and Gewandsznajder (2004) stress that the case study is characterised as a survey with data collection; the researcher will gradually identify topics and relationships between the analysis categories and, whenever necessary, creates new and or enhances earlier questions, and may generate the need to find new additional data.

The data were treated by analysing the qualitative content, considering the discussions about the categories of analysis of the information collected during the interview, now presented in Table 1 below.

Table 1: Analysis categories

\begin{tabular}{|c|c|c|}
\hline Categories & Subcategories & Authors \\
\hline Inventories & $\begin{array}{l}\text { Predicted demand } \\
\text { Consumer growth } \\
\text { Resupply lead time } \\
\text { New inputs }\end{array}$ & $\begin{array}{l}\text { Ballou (2007); Bowersox et al. } \\
\text { (2013); Virgulino \& Figueiredo } \\
\text { (2018); Assunção et al. (2020) }\end{array}$ \\
\hline Transport & $\begin{array}{l}\text { Distance covered } \\
\text { Transport cost }\end{array}$ & $\begin{array}{l}\text { Ballou (2007); Bowersox et al. } \\
\text { (2013); Assunção et al. (2020) }\end{array}$ \\
\hline Procurement & $\begin{array}{l}\text { Negotiation } \\
\text { Selection of suppliers } \\
\text { Delivery follow-up }\end{array}$ & $\begin{array}{l}\text { Mentzer et al. (2004); Ballou } \\
\text { (2007); Bowersox et al. (2013); } \\
\text { Assunção et al. (2020); }\end{array}$ \\
\hline Collaborators & $\begin{array}{l}\text { Capacity building } \\
\text { Outsourcing } \\
\text { Sickness } \\
\text { Staffing }\end{array}$ & Assunção et al. (2020) \\
\hline Storage and handling & $\begin{array}{l}\text { Fleet } \\
\text { Transfer lead time } \\
\text { Handling } \\
\text { Depot }\end{array}$ & $\begin{array}{l}\text { Swafford, Ghosh \& Murthy (2006); } \\
\text { Ballou (2007); Bowersox et al. } \\
\text { (2013); Assunção et al. (2020) }\end{array}$ \\
\hline
\end{tabular}

Source: Prepared by authors based on the literature (2020).

According to Figure 1, the survey design consists of four stages, as follows: the first stage addressed the analysis of the literature in order to subsidise the survey's content. Next, the second stage consisted of the transcription of the replies obtained from the semistructured interview script videoconferenced in July 2020, with the operations manager of the study's focus company, selected because he is a professional who has worked in all planning and implementation stages of the firm's logistics policy in response to the pandemic period. 
The third stage consisted of returning the transcription of the collected data to the interviewee in order to supplement the information obtained and to also confirm its authenticity or reject the researcher's interpretations (Zanelli, 2002). Lastly, the fourth stage was a discussion on the changes in logistics of the funeral industry, in line with the government actions proposed by the federal agencies.

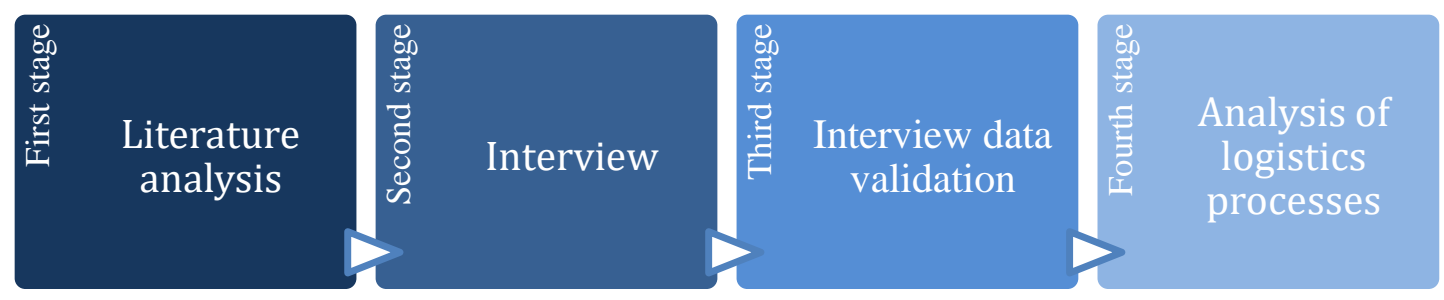

Figure 1: Survey Design

The firm in the case study is a benchmark funeral organisation in the Northeastern region of Brazil, having over 70 years' experience in the market in the states of Rio Grande do Norte, Pernambuco and Paraíba. The firm offers a variety of services, such as video transmission of funerals to distant family members, and pet cremation as a competitive edge, and has more than 1000 collaborators in its employment.

\section{RESULTS AND DISCUSSION}

Funeral logistics, according to the interviewed manager, is complex, requiring careful attention in every process inherent to accomplishing the service. With the pandemic, the logistics processes have become even more complicated, involving stricter safety protocols in body handling and treatment, considering imminent contamination, in line with the comments by Assunção et al. (2020) regarding the restrictions imposed on the logistics processes by the COVID-19 pandemic. Consequently, there has been a change in the firm's logistics policy, to the extent that processes regarding procurement, storage and handling, transport and inventories have been adapted to the requirements imposed by the emergency situation in order to achieve the strategic objectives described by Mentzer et al. (2004). The complexity of logistics operations is evident in the interviewee's comments:

"The time taken to collect the body from the hospital, which used to take approximately 50 minutes, is now up to five hours, initially because of the clearance time of the body, and later due to the rise in number of burials, with ever increasing demand on the fleet to provide the transfers."

This change in the transfer logistics flow increased the body handling time, diverging from the notes by Ballou (2007) and Bowersox et al. (2013), who assert that limited movement is necessary in logistics processes. In the logistics flow, a drop in the process lead time was observed, since the funeral itself was restricted to a maximum of three hours and with reduced presence of mourners at the funeral ceremonies. 
Given a scenario dominated by uncertainties, the start of measuring the demand, in the manager's opinion, was marked by the thought: "What's going to happen next?! Aspects present in inventory planning - what, how much and how - have given a more complex and challenging connotation, as already mentioned by Virgulino and Figueiredo (2018) regarding the complexity of the funeral industry, even prior to the COVID-19 pandemic.

The "calculations" for estimating resupply requirements were based then on the existing population, consisting of clients who have adhered to the firm's plans. One aspect worth mentioning is that the directors established that even within a pandemic context, which would exempt the firm from meeting its obligations under the exclusion clause used in such contracts, it chose to maintain all service covers of the funeral plans of its insured parties.

Also to set the replacement quantity, the background of existing deaths was analysed without considering the influence of the pandemic. An assessment was made of the profile of the firm's clients, but also data were collected concerning the evolution of the pandemic, including the number of deaths and profile of the victims, as recommended by Pellegrini and Fogliatto (2001), and Julianelli (2020).

Since the Brazilian data concerning the pandemic were still incipient, data from other countries were also considered. And while this appropriation was occurring, the complexity of the scenario was being confirmed. What would be the resulting impact on the regular scenario experienced by the firm? The comparison between the logistics processes before and during the pandemic is described in Table 2.

Table 2: Changes in the logistics processes of the funeral services based on the COVID-19 pandemic

\begin{tabular}{c|l|l}
\hline & Before the pandemic & \multicolumn{1}{c}{ During the pandemic } \\
\hline Collaborators & $\begin{array}{l}\text { Measured according to } \\
\text { the demand for activities } \\
\text { of the funeral group }\end{array}$ & $\begin{array}{l}\text { Collaborators were falling sick, many of them due to the } \\
\text { COVID-19, others suspected, which culminated in 14-day } \\
\text { isolation, in addition to employees off work for mental health } \\
\text { reasons. In this process, it was decided to outsource some } \\
\text { services because of people's reluctance and fear of falling sick, } \\
\text { including those that had been approved in the selection } \\
\text { process. Moreover, employees' vacations were suspended. }\end{array}$ \\
\hline $\begin{array}{c}\text { Demand } \\
\text { studies }\end{array}$ & $\begin{array}{l}\text { The demand was studied } \\
\text { based on the company's } \\
\text { past performance but } \\
\text { with fluctuation and } \\
\text { unpredictability, } \\
\text { characteristic of the } \\
\text { funeral sector }\end{array}$ & $\begin{array}{l}\text { Studies were undertaken comparing local prospects with } \\
\text { international data in order to predict the exponential rise in } \\
\text { demand for services. Since it was an absolutely seasonal } \\
\text { period, the demand was unpredictable. }\end{array}$ \\
\hline
\end{tabular}




\begin{tabular}{|c|c|c|}
\hline Procurement & $\begin{array}{l}\text { Inputs were often } \\
\text { procured from certain } \\
\text { suppliers, in both the } \\
\text { Northeast and other } \\
\text { regions in the country. }\end{array}$ & $\begin{array}{l}\text { The procurement sector was extended, doubling its } \\
\text { negotiation capacity by contracting employees. Procurement } \\
\text { was followed up on a daily basis with ongoing negotiations, } \\
\text { especially with regard to essential materials for the firm's } \\
\text { operations during the pandemic, namely: facemasks, alcohol } \\
\text { gel, urns ( } 90 \% \text { now procured in São Paulo) and flowers. This } \\
\text { new team began to negotiate PPE directly with the } \\
\text { manufacturers in order to tackle the shortage of materials, } \\
\text { with autonomy for negotiations. There was also a search for } \\
\text { new suppliers that could subsidise the perceived demand. }\end{array}$ \\
\hline Inventories & $\begin{array}{l}\text { The inventories had a one } \\
\text { month security of } \\
\text { balance for material } \\
\text { inventories }\end{array}$ & $\begin{array}{l}\text { At first, as a strategy, a four-month material consumption was } \\
\text { adopted, which was achieved with the PPE (facemasks, aprons, } \\
\text { overalls, liquids for alcohol gel procedures and other urn } \\
\text { component inputs). However, as a result of the shortage in } \\
\text { used materials and especially the urn market, a two-month } \\
\text { stock was adopted as a contingency, with daily checking of } \\
\text { inventories and systematic follow-up with the procurement } \\
\text { sector. Concerning flowers, a disproportional growth was } \\
\text { found in the sale of wreaths and bouquets, which resulted in a } \\
\text { practically just-in-time system, with almost zero stock. }\end{array}$ \\
\hline Storage & $\begin{array}{l}\text { The inventories were } \\
\text { distributed through the } \\
\text { group's bases throughout } \\
\text { the Northeast }\end{array}$ & $\begin{array}{l}\text { A temporary warehouse was then used to ensure safekeeping } \\
\text { of the materials necessary for the management of funeral } \\
\text { processes during the pandemic. This depository was the } \\
\text { cemetery still under construction in the town of São Gonçalo } \\
\text { do Amarante, state of Rio Grande do Norte (RN). }\end{array}$ \\
\hline Fleet & $\begin{array}{l}\text { The fleet was used at the } \\
\text { bases, depending on } \\
\text { predicted demand }\end{array}$ & $\begin{array}{l}\text { The fleet was now mobile, depending on the need per base. } \\
\text { Since the first epicentre among the group's bases was Recife, } \\
\text { in Pernambuco State (PE), hearses and workforce were moved } \\
\text { to that base to balance the demand. New cars were also } \\
\text { procured, benefiting from the decrees authorising faster } \\
\text { regulation of number plates. The state control agencies also } \\
\text { authorised the extended use of cars already depreciated. }\end{array}$ \\
\hline
\end{tabular}

Therefore, as a starting point, given the manager's perception of the inventory policy to be adopted in the pandemic period, it could be ascertained that:

"...being four months ahead of stock plus safety inventory, so that the team could make endeavour to facilitate supplies. In continuation, the team's endeavours were somewhat challenging."

The physical supply practice suggests the formation of partnerships with supply sources, implying a smaller number of suppliers, corroborated by the comments of Assunção et al. (2020) with regard to a more flexible approach and search for new suppliers before the crisis. However, the pandemic was causing a scarcity of items. In the funeral industry, in turn, the rising number of deaths signalled an upward trend in inputs. In fact, the firm's supplier base was now managing orders proportionally; that is, given the available stock, a move was 
made to attend its clients, considering their purchase history and providing the quantity from those percentages, as stated by the interviewee:

"the procurement team then began to look to increase its supply bases. Aspects such as distance, bearing in mind transport costs, were put aside. The idea was to ensure the supply of the inventory in order to avoid interruption in providing the services".

As a result, negotiations were made to triple suppliers for each input that were situated in remote regions, matching the results of Virgulino and Figueiredo (2018), who portray Southeast Brazil as the principal supplier of funeral urns.

The situation of rising demand in the funeral industry now conveys the idea of increased billing. However, according to the manager, what the firm was experiencing was different:

"expenses increased and revenues dropped. The senior management's position was to maintain the current prices. Restatement was at the start of the year, as expected, that is, before the pandemic."

The increase in these expenses, in addition to the shortage of supplies and consequent input price rise, plus higher transport costs given the distances travelled, highlight the necessary changes implemented in the internal logistics adopted by the firm - in keeping with the ideas of Assunção et al. (2020), considering the complexity already expressed by Bowersox, Closs, Cooper and Bowersox (2013) -, which includes the funeral services, transfer of bodies, as well as adopting the health protocols to be implemented.

In relation to the transfer, the fleet was insufficient due to the increasing number of collections. But the solution to this problem was not restricted to the purchase of a vehicle, since it would have to be converted. Moreover, this necessary adaptation implies a longer licensing process: the critical situation caused by the pandemic permitted the licensing authorities to allow the hearses to run without licence plates. The manager also added in his report that:

"it is customary to renew the fleet, but this would occur only after selling the old hearses. In the pandemic situation this did not happen. In order to meet the demand, not only did we have to procure vehicles, but also keep the existing ones, increasing costs even further."

There was also a change in the flow of funeral services, restricted to a reduced number of mourners and timetable. They were also concentrated in the actual cemetery, doing away with funeral homes in order to reduce the funeral cortege. This change involved the installation of structures, such as tents, incurring even higher costs. When the death was the result of COVID-19, the ceremony was restricted to burial without the traditional Western funerals described by Jacobs (2008) and Rugg (2020). 
Therefore, the revenue from funerals was affected. Sales associated with the funeral ceremonies dropped. The company had to not only revise its services but also develop means to provide the families with the support from friends, for example, despite the imposed limitations, considering social isolation. An alternative was to adopt technological resources using online funeral transmission, in addition to the space allocated to recording virtual messages, modernising the funeral business models debated by Sloane (1991); Kopp and Kemp (2007); Akyel (2011); and Rugg (2020).

The firm also had to develop health protocols, requiring not only specific materials for disinfection and personal protection but also capacity building for the employees. In fact, procurement of protective equipment was problematic, and attempts were made to establish a partnership with a foreign group. In fact, the supply shortage in this category was so significant that, according to the interviewee,

"a specific group was set up only to focus on this supply".

The manager also highlighted another challenge: "to deal with employee fear". In his report, he expressed that despite the fact that no COVID-19 related death had been recorded in his team, some tests had been positive. So, both the infected employee and people with whom he had been in contact were quarantined. This did not only cause psychological impact in the workplace, but also caused operational upsets, since employee absenteeism required substitutions due to the upward trending demand for services rather than their ceasing to exist. The solution was to outsource the workforce for the more operational posts.

Given this new reality, the manager emphasised that "it was impossible to define the processes in advance". And there were three outstanding problems:

"to define and gather data to help measure the inventory; to procure personal protection equipment; and human capital to overcome the adversities arising from the pandemic scenario."

The interviewee's conclusions on the pandemic-imposed troubles match those already mentioned by Virgulino and Figueiredo (2018), referring to the complexity of the funeral industry, as well as to the adversities imposed on the logistics processes as a result of the COVID-19 pandemic, demonstrated by Assunção et al. (2020).

\section{CONCLUSIONS}

The purpose of the study was to understand the change in actions and processes made in the logistics policy of a firm in the funeral industry operating in Northeast Brazil, to respond to the COVID-19 pandemic period. 
The main result confirmed that the context of the COVID-19 pandemic generated resilient actions by the firm and a need to readapt its logistics policy, covering the transport, procurement and inventory activities in order to guarantee the continued provision of funeral services without detriment to the consumers of funeral plans and possible new clients.

The unpredictability of the demand plus the need to develop services considered essential in a pandemic, such as funerals, had led the company to find new suppliers, increase stocks of basic and health inputs and increase the vehicle fleet, since it was necessary to optimise the processes involved with the increased transfer of bodies. From this perspective, it should be highlighted that the firm's logistics policy was built dynamically as the pandemic developed, given the unpredictability caused by the economic-operational instability in the service sector and especially in funeral services.

Concerning the limitations, mention is made of how difficult it is to find in the literature studies on logistics in the funeral industry, covering the inventory, procurement and transport management, and other activities that could further reinforce the discussion raised herein.

As a suggestion for future studies, it is recommended to undertake studies with other companies in the funeral service industry, whose logistics processes have also been affected by the COVID-19 pandemic, especially with regard to impacts on the links in the chain both downstream and upstream.

\section{REFERENCES}

Akyel, D. (2011, June 23). The economization of the sacred: The transformation of the death care industry in Germany. Paper presented at the Annual Meeting of the SASE Annual Conference, Spain: Autonomous University of Madrid. Retrieved from http://citation.allacademic.com/meta/p498209 index.html

Alves-Mazzoti, A.J. (2004). As ciências sociais são ciências. [Social sciences are sciences] AlvesMazzoti, A.J; Gewandsznajder, F. The method in natural and social sciences - a qualitative and quantitative study, 2, 112-128.

Assunção, M.V.D.; Medeiros, M.; Moreira, L.N.R.; Paiva, I.V.L., \& de Souza Paes, D.C.A. (2020). Resilience of the Brazilian supply chains due to the impacts of COVID-19. HOLOS, $5,1-20$.

Bajardi, P.; Poletto, C.; Ramasco, J.J.; Tizzoni, M.; Colizza, V., \& Vespignani, A. (2011). Human mobility networks, travel restrictions, and the global spread of 2009 H1N1 Pandemic. PLoS One, 6(1), e16591.http://doi.org/10.1371/journal.pone.0016591

Ballou, R.H. (2007). The evolution and future of logistics and supply chain management. European Business Review, 19(4), 332 - 348. 
Bowersox, D.J.; Closs, D.J.; Cooper, M.B., \& Bowersox, J. (2013). Supply Chain Logistics Management. McGraw Bill International Edition. New York, NY, USA.

Brooks, S.K.; Webster, R.K.; Smith, L.E.; Woodland, L.; Wessely, S.; Greenberg, N., \& Rubin, G.J. (2020). The psychological impact of quarantine and how to reduce it: Rapid review of the evidence. The Lancet, 395(102227), 912-20. http://doi.org/10.1016/S0140$\underline{6736(20) 30460-8}$

Eisenhardt, K. M. (1989). Building theories from case study research. Academy of Management Review, 14(4), 532-550.

Fan, Y.; Zhao, K.; Shi, Z.-L., \& Zhou, P. Bat Coronaviruses in China. Viruses 2019, 11, 210.

Goody, J. \& Poppi, C. (1994). Flowers and bones: Approaches to the dead in Anglo and Italian cemeteries. Comparative Studies in Society and History, 36, 146-175.

Hadders, H. (2013). Cremation in Norway: Regulation, changes and challenges. Mortality (Abingdon, England), 18(2), 195-213.

Hartley D. \& Perencevich E. Public health interventions for COVID-19: Emerging evidence and implications for an evolving public health crisis. JAMA. 2020; (Published online April 10, 2020) https://doi.org/10.1001/jama.2020.5910

Hui \& Guan, Y. (2006). Prevalence and Genetic Diversity of Coronaviruses in Bats from China. Journal of Virology. 80. 7481-90. 10.1128/JVI.00697-06.

Jacobs, J. (2008). Houses of life: Jewish cemeteries of Europe. Frances Lincoln.

Julianelli, L. Impacto da crise econômica na demanda: como melhorar a previsão de vendas? [Impact of the economic crisis on demand: How are sales forecasts improved?] Logistics and Supply Chain Specialists, 2015. Available at: https://www.ilos.com.br/web/impacto-dacrise-economica-na-demanda-como-melhorar-a-previsao-de-vendas/. Accessed: $4 / 8 / 2020$.

Klaufus, C. (2016). "The dead are killing the living": Spatial justice, funerary services and cemetery land use in urban Colombia. Habitat International, 54, 74-76.

Kopp, S. \& Kemp, E. (2007). The death care industry: A review of regulatory and consumer issues. Journal of Consumer Affairs, 41(1), 150-173.

Liu Y.; Gayle A.A.; Wilder-Smith A., \& Rocklöv J. The reproductive number of COVID-19 is higher compared to SARS coronavirus. J Travel Med. 2020 Mar;27(2):taaa021.

Mathijssen, B. \& Venhorst, C. (2019). Funerary practices in the Netherlands. Emerald Publishing.

Mentzer, J.T.; DeWitt, W.; Keebler, J.S.; Min, S.; Nix, N.W.; Smith, C.D. \& Zacharia, Z.G. (2001). Defining Supply Chain Management. Journal of Business Logistics, 22(2), 1-25. 
Peiris J.S.M.; Lai S.T; Poon L.L.M. et al. Coronavirus as a possible cause of severe acute respiratory syndrome. Lancet 2003;361:1319-1325

Pellegrini, F.R., \& Fogliatto, Flávio S. (2001). Passos para Implantação de Sistemas de Previsão de Demanda-Técnicas e Estudo de Caso. [Steps to implement demand forecast systems - Techniques and Case Study] In: Revista PRODUÇÃO, v. 11 n. 1, November 2001.

Rugg, J. (2015). Churchyard and cemetery (pp. 444). Manchester: Manchester University Press.

Rugg, J. (2020). Social justice and cemetery systems. Death Studies, 1-14.

Rugg, J., \& Parsons, B. (2018). Funerary practices in England and Wales. Emerald Publishing.

Shi, Z., \& Hu, Z. (2008). A review of studies on animal reservoirs of the SARS coronavirus. Virus research, 133(1), 74-87. https://doi.org/10.1016/j.virusres.2007.03.012

Silva, J.N.F.; Queiróz, C.S.R., \& Soares, A.P. (2018). GESTÃO DE MATERIAIS NO SERVIÇO PÚBLICO: proposição de um modelo para os cemitérios de Rondonópolis-MT. [Materials Management in Public Service: Proposed model for cemeteries in Rondonópolis, Mato Grosso state] Revista Estudos e Pesquisas em Administração, 2(1), 118-133.

Sloane, D. (1991). The last great necessity: Cemeteries in American history (pp. 320). Baltimore: Johns Hopkins University Press.

Suzuki, H. (2000). The price of death, the funeral industry in contemporary Japan. Stanford: Stanford University Press.

Swafford, P.M.; Ghosh, S., \& Murthy, N. (2006). The antecedents of supply chain agility of a firm: scale development and model testing. Journal of Operations Management, 24(2), 170-188.

Tang, X.C.; Zhang, J.X., \& Zhang, S.Y. et al. Prevalence and genetic diversity of coronaviruses in bats from China. J Virol. 2006;80(15):7481-7490. doi:10.1128/JVI.00697-06

Virgulino, D.C.B., \& de Souza Figueiredo, G.L.A. (2018). Gestão de estoque no ramo de serviços funerários: Estudo de caso entre duas empresas no município de Araguaína-TO. [Inventory management in the funerary service industry: Case study between two companies in the municipality of Araguaina, Tocantins State] Facit Business and Technology Journal, 1(6).

Walter, T. (2005). Three ways to arrange a funeral: Mortuary variation in the modern West. Mortality, 10(3), 173-192.

Walter, T. (2012). Why different countries manage death differently: A comparative analysis of modern urban societies. The British Journal of Sociology, 63(1), 123-145.

Webster, R.G. Wet markets--a continuing source of severe acute respiratory syndrome and influenza? Lancet. 2004;363(9404):234-236. doi:10.1016/S0140-6736(03)15329-9 
White, D.B., \& Lo, B. A Framework for Rationing Ventilators and Critical Care Beds during the COVID-19 Pandemic. JAMA. 2020;323(18):1773-1774. doi:10.1001/jama.2020.5046

Wood, Cate. (2020). Infections without borders: A new coronavirus in Wuhan, China. British Journal of Nursing. 29. 166-167. 10.12968/bjon.2020.29.3.166.

World Health Organization (2007). Risk reduction and emergency preparedness: World Health Organization six-year strategy for the health sector and community capacity development. Retrieved 10 April 2020, from http://apps.who.int/iris/bitstream/handle/10665/ 43736/9789241595896_eng.pdf?sequence=1\&isAllowed=y

World Health Organization 2020. Coronavirus disease 2019 (COVID-19) situation report - 51 [Online]. Available at: https://www.who.int/docs/defaultsource/coronaviruse/situation-reports/20200311-sitrep-51-covid19.pdf?sfvrsn=1ba62e57_10 (Accessed: 1 April 2020).

World Health Organization. Weekly Epidemiological Record, 2013, vol. 88, 35 [full issue]. Weekly Epidemiological Record. 2013, 88, 3.

World Health Organization. WHO Director-General's opening remarks at the media briefing on COVID-19 - 11 March 2020. World Health Organization, [S. I.], p. 1, 11 March 2020. Available at: https://www.who.int/dg/speeches/detail/who-director-general-s-openingremarks-at-the-media-briefing-on-covid-19---11-Mar-2020. Accessed: 11 Aug 2020.65380.

Yin, R.K. (2018). Pesquisa qualitativa do início ao fim. [Qualitative study from start to finish] Penso Editora.

Zanelli, J.C. (2002). Pesquisa qualitativa em estudos da gestão de pessoas. [Qualitative survey in people management studies] Estudos de Psicologia (Natal), 7(SPE), 79-88."

\section{COMO CITAR ESTE ARTIGO:}

Assunção, M. V. D. de; Araújo, M. V. P. de; Rocha, F. A. F. da; Gonçalves, A. T. P.; Lima, J. I. M. P. de. Actions and changes in the logistics policy in pandemic times: a case study of a funeral home. (2020). Holos. 36(5), 1-15.

\section{SOBRE OS AUTORES}

\section{V. D. DE ASSUNÇÃO}

Possui Graduação em Engenharia de Produção/UFRN, MBA em Logística Empresarial pela Uni-RN, Mestrado em Administração/UFRN e Doutor em Ciência e Engenharia de Petróleo/UFRN. Professor do IFRN Campus SGA e Coordenador do Curso de Logística Campus SGA/IFRN. E-mail: marcus.assuncao@ifrn.edu.br ORCID ID: $\underline{\text { http://orcid.org/0000-0002-3384-1899 }}$ 


\section{V. P. DE ARAÚJO}

Possui graduação, mestrado e doutorado em Administração Atualmente exerce a função de chefe do Departamento de Administração da Universidade Federal do Rio Grande do Norte, onde atua como professora adjunta desde 2008. E-mail: valeriaaraujoufrn@ gmail.com

ORCID ID: https://orcid.org/0000-0001-6302-1173

\section{F. A. F. DA ROCHA}

Engenheira eletricista e administradora, mestrado em Engenharia Elétrica e doutorado em Administração. Professora de gestão e negócios do IFRN. E-mail: fabricia.rocha@ifrn.edu.br ORCID ID: https://orcid.org/0000-0001-9924-7334

\section{A. T. P. GONÇALVES}

Graduado em Administração, mestre em Engenharia de Produção e doutor em Administração. Atualmente é professor Adjunto da UFPE. E-mail: adm.andersontiago@ gmail.com

ORCID ID: https://orcid.org/0000-0002-7338-2180

\section{J. I. M. P. DE LIMA}

Bacharel em administração e mestrando em Administração. E-mail: jorge_italo_@outlook.com ORCID ID: https://orcid.org/0000-0002-4263-3549

Editor(a) Responsável: Francinaide de Lima Silva Nascimento Pareceristas Ad Hoc: DIEGO CRISTÓVÃO ALVES DE SOUZA PAES E CARLA TEIXEIRA ASSUNÇÃO

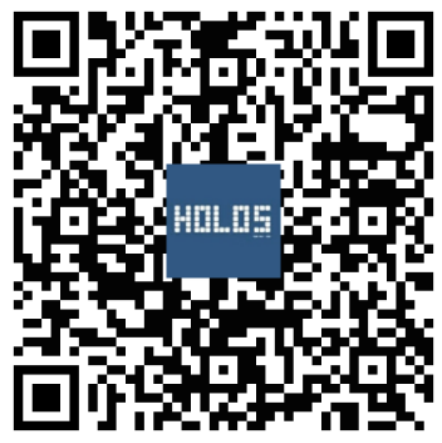

